\title{
Assessing treatment response to prophylactic lithium use in patients with bipolar disorder
}

\author{
Avaliação da resposta terapêutica ao tratamento de manutenção \\ com lítio em pacientes com transtorno afetivo bipolar \\ Luiz Fernando de Almeida Lima e Silva', Júlia Cunha Loureiro', Stephany Caroline Raposo Franco², \\ Marilza de Lima Santos³, Rodrigo Secolin³, Iscia Lopes-Cendes³, Clarissa de Rosalmeida Dantas', \\ Claudio E. M. Banzato ${ }^{1}$
}

\section{Keywords}

Bipolar disorder, psychotic disorders, lithium, treatment outcome, tobacco.

\section{Palavras-chave \\ Transtorno bipolar, transtornos psicóticos, lítio, resultado do tratamento, tabaco.}

\begin{abstract}
Objetive: To identify potential clinical and epidemiological predictors of long-term response to lithium treatment. Methods: A total of 40 adult outpatients followed in an university hospital, with confirmed diagnosis of bipolar disorder and with history of lithium use for at least a six months period, had their response to this medication assessed through the use of a standardized instrument. The ALDA scale is based on retrospective clinical data, in our study assessed through a thoroughly reviewed of the medical charts, and is used to evaluate the clinical improvement with the treatment (Criterion A), corrected by the acknowledgement of possible confounding factors, such as duration of the treatment, compliance and concomitant use of additional medications (Criterion B), in order to estimate the response that can be specifically attributable to lithium. Results: Our study found an inverse relation between the number of mood episodes with psychotic symptoms and lithium treatment outcome. Conclusion: The results reinforce the hypothesis that lithium seems to be less efficacious in patients with bipolar disorder who present psychotic symptoms.
\end{abstract}

\section{RESUMO}

Objetivo: Identificar potenciais preditores clínicos e epidemiológicos de resposta terapêutica ao uso prolongado de lítio. Métodos: Um total de 40 pacientes adultos em tratamento ambulatorial em um hospital universitário, com diagnóstico confirmado de transtorno afetivo bipolar e história de pelo menos seis meses de uso de lítio, teve sua resposta a essa medicação avaliada com a utilização de um instrumento padronizado. A escala ALDA leva em consideração informações clínicas obtidas de forma retrospectiva, em nosso estudo, por meio de minuciosa revisão dos prontuários médicos, para julgar a melhora clínica obtida com o tratamento (Critério A), corrigida pela identificação de possíveis fatores confundidores, tais como duração do tratamento, adesão e uso concomitante de outras drogas (Critério B), de forma a estimar a resposta que pode ser atribuída especificamente ao uso do lítio. Resultados: Nosso estudo encontrou uma relação inversa entre o número de episódios de humor com a presença de sintomas psicóticos e o desfecho no tratamento com lítio. Conclusão: Esses resultados reforçam a hipótese de que o lítio parece ser menos eficaz em pacientes com transtorno afetivo bipolar que manifestam sintomas psicóticos.

1 University of Campinas (Unicamp), Medical School, Department of Psychiatry.

2 Unicamp, Medical School.

3 Unicamp, Medical School, Department of Medical Genetics.

Address for correspondence: Luiz Fernando de Almeida Lima e Silva

Rua Tessália Vieira de Camargo, 126

Cidade Universitária "Zeferino Vaz", Barão Geraldo

13083-970 - Campinas, SP, Brazil

Telephone: (+55 19) 99635-6540

E-mail: luizfals@hotmail.com 


\section{INTRODUCTION}

Bipolar disorder (BD) is a chronic and severe mental illness, with an estimated prevalence of $1 \%$ in the general population $^{1-4}$. The first mood episodes usually appears in adolescence or early adulthood, between 20 and 30 years of age ${ }^{5}$, and the most prevalent clinical form of the disorder is the occurrence of mania or hypomania, interspersed with episodes of depression and periods of euthymia. Taking in account patients with subthreshold mood symptoms, the prevalence of bipolar spectrum disorders in the community may rise up to $6.4 \%{ }^{6}$. The disorder is strongly associated with reduced quality of life, high degree of impairment, disability and higher health care costs ${ }^{7-9}$. Psychiatric comorbidity in $\mathrm{BD}$ is also significant, with a lifetime prevalence of $65 \%$ for other Axis-I (DSM) disorders ${ }^{10}$.

Since the famous paper from Cade (1949), in which he describes the use of lithium in patients with $B D$, many studies have explored the pharmacological treatment options for acute mania, depression, and BD maintenance. Still, considering the myriad of treatment alternatives with Food and Drug Administration (FDA) approval, lithium even now stands as a major option in bipolar maintenance ${ }^{11}$. Lithium received the FDA approval for the prophylactic treatment of BP in 1974, but only in 1994 the first study to assess its efficacy using a control group was published ${ }^{12}$. Later, in 2000, Bowden et al., published the first randomized double blind study with lithium against placebo ${ }^{13}$.

In this context, the attempts to identify possible predictors to lithium response date back to the first publications involving its prophylactic use in mood disorders. Since then, many studies explored the predictive power of a number of variables, with controversial results ${ }^{14}$. Nevertheless, available data in the literature suggest that lithium therapy seems to be more effective in patients with bipolar disorder presenting the so called "core phenotype", that is, with an episodic course, family history of BD, family history of lithium response, absence of rapid cycling and low comorbidity rate ${ }^{15}$. Furthermore, patients with atypical features, including mood incongruent psychosis, mixed states, rapid cycling, and the presence of psychiatric comorbidity, seem to have lower rates of response to lithium therapy ${ }^{16-19}$.

Concerning specifically the presence of psychotic symptoms in BD, more than half of the patients with BD develop psychotic symptoms at some point of their lives ${ }^{18}$, and the hypothesis that patients with psychotic features, like paranoid delusion and other formal thought disorder, have worst response to prophylactic lithium is old ${ }^{17}$. However, the attempts to confirm the predictive value of psychotic symptoms on the outcome of patients with BD and treated with lithium showed mixed and inconclusive results ${ }^{14}$.

And important aspect involving the predictive value of psychotic symptoms in BD concerns the definition of psycho- sis. In the most frequently adopted model, the psychotic symptoms are divided in mood congruent or mood incongruent. Some data in the literature point to worst treatment outcomes when mood incongruent psychosis is present ${ }^{14}$, what occurs in up to $55 \%$ of the patients with BD $^{20}$.

Nevertheless, the literature shows no universally accepted definition of mood incongruent psychosis and even the identification of psychotic features in patients with BD may be challenging ${ }^{21}$. The most commonly adopted definition includes symptoms not directly related to mood polarity, like the presence of paranoid and reference delusions, insertion

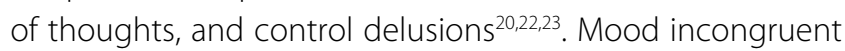
psychosis is associated with worst psychosocial outcomes, possibly because it is related to a higher overall severity of the disorder ${ }^{20}$, though diagnostic issues (such as differential diagnosis with schizophrenia spectrum disorders) may also play a role. Data in the literature also suggest that these patients have a poor response to prophylactic lithium ${ }^{24}$.

This study aims to evaluate, using a standardized method (the ALDA scale), the therapeutic response to lithium in the maintenance treatment of $\mathrm{BD}$, as to assess possible clinical predictors of lithium response. It is important to notice that the present paper was conceived within the framework of a larger genetic study, the ConLiGen, a Genome-wide association study (GWAS) with the objective to determine the phenotype of lithium response, and of which we represent the Brazilian branch. The results presented here are, therefore, a preliminary analysis of the clinical and sociodemographical data of the studied population. The ALDA scale is the instrument adopted by the ConLiGen to determine lithium response.

\section{METHODS}

From August 2013 to August 2014, outpatients consecutively seen at the Unicamp General Hospital Psychiatric Clinic with confirmed diagnosis of bipolar disorder (according to DSM-IV) and history of current or previous lithium use were identified by one of the researchers (LFALS) during their routine psychiatric consultation and invited to participate in the study (which implied in contributing with a blood sample for genetic analysis). Only patients with age $\geq 18$ years and who used lithium for at least a 6 months period were included. Patients with intellectual disability, neuropsychiatric symptoms possibly related to clinical illness, or inability to understand the study objectives and to freely consent to participate were excluded.

The 40 patients who consented to participate had their medical charts thoroughly reviewed in order to collect clinical and sociodemographic data. We used the collected information to evaluate lithium response in the maintenance treatment of $\mathrm{BD}$, and to explore possible predictors of lithium response. 


\section{Studied variables}

\section{Response to lithium in the maintenance treatment of bipolar disorder}

It can be challenging to evaluate improvement in patients treated in a clinical scenario and not following a strict research protocol. For this purpose, the ALDA scale is considered a valuable tool, and as far as our knowledge goes, is the only instrument that allows to retrospectively assess clinical improvement with lithium treatment in a standardized manner.

The ALDA scale is based on retrospective clinical data and is divided in two major criteria, namely A and B. Criterion $A$ is used to determine the relation between clinical improvement and the treatment (illness activity while in lithium use), with scores ranging from 10 (complete response) to 0 (no change or worsening).

Criterion B concerns possible confounding factors, and is used to establish whether there is a causal relationship between clinical improvement and the treatment. Score 0,1 or 2 points for each item: number of episodes before the treatment (B1), frequency of episode before the treatment (B2), duration of the treatment (B3), compliance during period(s) of stability (B4), and use of additional medications during the periods of stability (B5).

The ALDA scale total score (TA) is obtained by subtracting $B$ from A. This way, it allows a categorical approach (above or below a cut-off score), or a dimensional approach in the assessment of clinical improvement with lithium treatment ${ }^{25,26}$. The Brazilian version of the ALDA scale adapted to Portuguese from the original English instrument within the context of this study is provided in the Appendix 1.

To use the ALDA scale, the first step is to determine the longest period in which lithium was used and well documented, with information regarding clinical improvement, frequency and duration of mood episodes, total duration of the treatment, compliance during treatment (including drug levels within therapeutic range), and description of additional medication use, including antidepressants and antipsychotics.

In our study, two different researchers (LFALS, JCL) were trained using the clinical vignettes from The International Consortium on Lithium Genetics (ConLiGen), in order to calibrate the scoring of the scale; after that they reviewed the clinical charts. This procedure generated a single data bank, including all the 40 patients, on which both the researchers based their independent score of the ALDA scale. Later they debated about their individual ratings aiming for a consensus score for each of the ALDA scale items. These consensus scores were used together with the other variables (described below) to explore possible predictors of lithium response.

\section{Clinical and sociodemographical variables}

Demographic and clinical variables were also obtained in this process such as gender, education, age of onset and frequency of mood episodes, presence and frequency of psychotic symptoms, suicide attempts, hospitalization, electroconvulsive therapy (ECT), use of tobacco, alcohol and other drugs, and family history of mental disorder.

The timeframe considered in this study was from the onset of the illness (that is, first episode of depression or mania) until the beginning of the interval chosen for the scoring of the ALDA scale. This approach was meant to test the predictive power of the studied variables in regard to the lithium response.

To determine the relation between these variables and the scores of the ALDA scale, all data was transformed in ranks and submitted to a logistic regression and linear regression (univariate and multivariate models). The significance level adopted is this study was of 5\%.

This study was approved by the Unicamp Research Ethics Review Board and a signed consent form was obtained from all patients prior to entering the study.

\section{RESULTS}

\section{Sample description}

Of the 40 patients with BD assessed in this study, 15 were males and 25 were females, with a mean age of $40.03( \pm 3.08)$ years. Forty percent never got married, and $57.5 \%$ never had children. Regarding education, most of our patients completed high school (28.21\%) or had incomplete superior education (23.08\%), with a mean of $9.72( \pm 4.08)$ years of scholarship. Only $42.5 \%$ could be considered economically active.

\section{Clinical variables}

The mean age of onset of mood symptoms was 24.18 $( \pm 9.18)$ years, while the length of the disorder until the chosen period for scoring the ALDA scale was of 12.85 ( \pm 9.18) years. Manic symptoms manifested slightly earlier than depressive symptoms (26.55 vs. 28.14 years), but mixed symptoms showed the smaller mean age of onset, of 24.55 years. A detailed description is shown on Table 1.

Concerning the manifestation of psychosis in $\mathrm{BD}$, our study found that $67.5 \%$ of the patients $(\mathrm{N}=27)$ presented with psychotic symptoms at some point of their clinical course, including delusions, hallucinations and severe disorganized behavior. The mean number of mood episodes with psychotic features in this group of patients was of $2.77( \pm 2.62)$, with median of 2.00 .

In the majority of the patients who presented psychotic symptoms at some point (62.96\%), such symptoms occurred exclusively on manic episodes; only in $3.7 \%$ of the cases this symptoms occurred exclusively in depressive episodes. In $33.33 \%$ of the patients, the occurrence of psychotic features happened in both mania and depression. Most of the patients (75.86\%) had at least one episode with mood incongruent psychotic symptoms, that is, paranoid and reference delusions, auditory hallucinations and severe disorganized behavior. 
Table 1. Clinical features of the mood episodes

\begin{tabular}{|c|c|c|c|c|c|c|}
\hline Variable & $\mathrm{N}^{*}$ & Mean & S.D. & Median & Min & Max \\
\hline Age of onset of mood symptoms & 40 & 24.18 & 9.18 & 22.00 & 12.00 & 49.00 \\
\hline Age at the beginning of the analyzed ALDA period & 40 & 34.90 & 13.22 & 32.00 & 16.00 & 68.00 \\
\hline Number of manic episodes & 40 & 3.23 & 3.08 & 2.00 & 0.00 & 13.00 \\
\hline Age of first manic episode & 38 & 26.55 & 10.50 & 25.00 & 14.00 & 57.00 \\
\hline Number of hypomanic episodes & 40 & 0.53 & 0.85 & 0.00 & 0.00 & 3.00 \\
\hline Age of First hypomanic episode & 13 & 28.31 & 9.89 & 23.00 & 16.00 & 44.00 \\
\hline Number of depressive episodes & 40 & 1.53 & 1.95 & 1.00 & 0.00 & 10.00 \\
\hline Age of first depressive episode & 28 & 28.14 & 12.23 & 26.50 & 12.00 & 62.00 \\
\hline Number of mixed episodes & 40 & 0.45 & 1.40 & 0.00 & 0.00 & 7.00 \\
\hline Age of first mixed episode & 06 & 24.50 & 4.28 & 22.00 & 21.00 & 30.00 \\
\hline Total number of mood episodes & 40 & 5.75 & 4.46 & 4.00 & 1.00 & 20.00 \\
\hline
\end{tabular}

${ }^{*} \mathrm{~N}<40$ are due to the nonoccurrence of a given phenomenon or, in some cases, to missing data.

Among the studied variables, there are those that point to a more severe clinical course, like history of suicide attempt. In our sample, $22.5 \%$ of the patients attempted suicide. The mean age of the first suicide attempt was 26.89 years ( \pm 12.81$)$. In $28.57 \%$ of the cases, the patient had clinical complications with the need to receive medical support.

Other important evidence of clinical severity is the need for hospitalization. In the vast majority of the cases $(87.5 \%$; N $=35$ ), the patient was hospitalized at least once, with a mean of $3.4( \pm 2.51)$ hospital admissions per patient, and median of 2.0. Finally, 25\% had history of ECT treatment for mania, depression or mixed states.

Concerning the presence of comorbidity, at least one clinical disease was present in $40 \%$ of the cases, and at least one other psychiatric disorder was found $57.5 \%$ of the cases. Substance use disorders, including abusive use and dependence identified by the assistant doctor and reported in the medical chart, had a prevalence of $7.69 \%$ for alcohol related disorders and $10.0 \%$ for other drugs. History of current or previous tobacco use had a higher prevalence, of about one third of the patients (31.58\%).

In relation to the instituted maintenance treatment for $\mathrm{BD}$, the vast majority of the patients had history of current or previous use of more than one pharmacological agent beside lithium. The most frequent association was with antipsychotics (95.0\%), followed by anticonvulsants (80.0\%), benzodiazepines (60.0\%) and antidepressants (42.5\%).

Finally, concerning the presence of family history of mental disorder, it is interesting to notice that about $80 \%$ of the patients had family history of mood disorders, $20 \%$ for psychotic disorders and $42.5 \%$ for some other mental disorder, specified or not.

\section{Lithium response}

The consensus scores obtained for each of the ALDA scale items are presented in the Table 2.
Table 2. Consensus Scores for the ALDA Scale

\begin{tabular}{llllc}
\hline Variable & N & Mean & S.D. & Median \\
\hline ALDA A & 40 & 7.00 & 2.25 & 7.00 \\
ALDA B1 & 40 & 0.50 & 0.68 & 0.00 \\
ALDA B2 & 40 & 0.38 & 0.67 & 0.00 \\
ALDA B3 & 40 & 0.53 & 0.64 & 0.00 \\
ALDA B4 & 40 & 1.05 & 0.81 & 1.00 \\
ALDA B5 & 40 & 1.78 & 0.58 & 2.00 \\
ALDA BT & 40 & 4.23 & 1.79 & 4.00 \\
Total ALDA (A-B) & 40 & 2.78 & 3.08 & 3.00 \\
\hline
\end{tabular}

The mean duration of the selected intervals to score the scale was 37.35 months ( \pm 39.74 ), with a median of 24.5 months.

\section{Univariate and multivariate analysis}

Despite the large number of variables we have analyzed, only some of them were chosen to integrate the multivariate model. This choice was based in their distribution in the studied population and data regarding possible predictors to lithium response in the literature. The selected variables are exposed in Tables 3 and 4.

Concerning the analysis involving the TOTAL ALDA scores (A minus B), we highlight that only four patients had $T A \geq 7$, the most common cut-off score adopted in studies that use the scale. This distribution did not allow the creation of two distinct groups (responders vs. non-responders). Thus, we adopted a different approach to the data, and used the scores of Criterion $A$ as a continuous variable with the exclusion of patients with TB scores $>4$, a strategy also adopted by the ConLiGen ${ }^{27}$. As a result, we have obtained a subgroup of 26 patients, which was analyzed. The rationale for this approach is that patients with a high prevalence of confounders, that is, with high TOTAL B scores, can compromise the inference of causality between clinical improvement and lithium use. 
Table 3. Clinical predictors of lithium response - univariate linear regression analysis $(N=26)$

\begin{tabular}{|c|c|c|c|c|c|c|}
\hline Variable & N & DF & Parameter estimate & Standard error & Tvalue & $\mathrm{PR}>|\mathrm{T}|$ \\
\hline Gender & 26 & 1 & 0.93464 & 3.17072 & 0.29000 & 0.77070 \\
\hline Years of scholarship & 26 & 1 & -0.11763 & 0.33077 & -0.36000 & 0.72520 \\
\hline Age of onset & 26 & 1 & 0.25139 & 0.16900 & 1.49000 & 0.14990 \\
\hline Duration of the disorder (Before ALDA) & 26 & 1 & -0.00260 & 0.01380 & -0.19000 & 0.85210 \\
\hline Number of manic episodes & 26 & 1 & -0.24399 & 0.46058 & -0.53000 & 0.60120 \\
\hline Age of first manic episode & 26 & 1 & 0.04205 & 0.15313 & 0.27000 & 0.78620 \\
\hline Number of depressive episodes & 26 & 1 & -0.11900 & 0.69764 & -0.17000 & 0.86600 \\
\hline History of suicide attempt & 26 & 1 & 4.49624 & 3.28098 & 1.37000 & 0.18320 \\
\hline Presence of psychotic symptoms (yes or no) & 26 & 1 & -3.14379 & 3.11096 & -1.01000 & 0.32230 \\
\hline Number of mood episodes with psychotic symptoms & 26 & 1 & -0.95286 & 0.47727 & -2.00000 & 0.05730 \\
\hline History of tobacco use & 25 & 1 & 6.19481 & 2.73883 & 2.26000 & 0.03350 \\
\hline Family history of psychosis & 26 & 1 & -6.94318 & 3.94131 & -1.76000 & 0.09090 \\
\hline History of electroconvulsive treatment & 26 & 1 & -0.29323 & 3.40640 & -0.09000 & 0.93210 \\
\hline
\end{tabular}

Table 4. Patients with total b scores $>4$ - Multivariate linear regression analysis $(N=23)^{*}$

\begin{tabular}{|c|c|c|c|c|c|c|}
\hline Variable & Parameter estimate & Standard error & TypellsS & Fvalue & $P R>F$ & R2 parcial \\
\hline Number of mood episodes with psychotic symptoms & -1.24241 & 0.40396 & 314.23522 & 9.46 & 0.0060 & 0.2502 \\
\hline History of tobacco use & 7.66608 & 2.41712 & 334.15917 & 10.06 & 0.0048 & 0.2208 \\
\hline
\end{tabular}

* Selection criteria: stepwise.

The multivariate analysis $(\mathrm{N}=23)$, showed that the number of mood episodes with psychotic symptoms had and inverse relation with clinical improvement, accessed through criterion A of the ALDA scale (PE -1.24241). On the other hand, we have found a direct relation between clinical improvement and history of current or previous tobacco use (PE 7.66608)

\section{DISCUSSION}

The available data in the literature suggests that the prevalence of $\mathrm{BD}$ is similar in males and females ${ }^{28}$, but the clinical presentation and the received treatment can differ significantly between sexes. Female patients are treated more often with antidepressants, benzodiazepines, neuroleptics, lamotrigine and psychotherapy than their male counterparts (52). In our sample, concerning lithium response, we have not found difference between male and female patients, which is in consonance with the data in the literature ${ }^{29,30}$.

As for the age of onset of mood symptoms, it is considered one of the variables with potential do discriminate patients with BD in clinical subgroups. Nevertheless, the validity of this age based groups is uncertain, and the criteria used to discriminate the patients are not consensual ${ }^{5,31}$. We found no relation between age of onset and lithium response.

Concerning the number and frequency of mood episodes, data in the literature suggest that a higher duration of the disorder or a higher frequency (number) of mood episodes is directly related with morbidity, including higher rates of mood cycling and length of the mood episodes ${ }^{32}$. However, other studies like the systematic review conducted by Kleindienst et al. found no relation between the number of mood episodes and lithium response in patients with $\mathrm{BD}^{14}$. Our results also found no relation between the number of episodes of mania, depression, hypomania or mixed states and the clinical response to prophylactic lithium.

Bipolar disorder is strongly related with premature mortality, with rates up to 2-3 times higher than in general population $^{33}$. Suicide is the main cause of early mortality in this patients $^{34}$. During the course of their lives, approximately 50\% of the patients with bipolar disorder attempt suicide ${ }^{35}$, and between $11 \%$ and $19 \%$ commit suicide ${ }^{36}$. In our study, $22.5 \%$ of the patients attempted suicide, which is lower than the rates reported in the literature. We have not found positive or negative relation between history of suicide attempt and clinical improvement with prophylactic lithium.

We have also explored the relation of history of electroconvulsive therapy $(E C T)$ and clinical improvement with lithium use. ECT can be a valuable therapeutic option in patients with $\mathrm{BD}$, in mania or depressive episodes that are refractory to pharmacotherapy. In our sample, $25 \%$ of the patients had history of ECT treatment, prevalence similar with the one found in the literature. We did not found any relation between lithium treatment improvement and history of ECT. 
Finally, an interesting finding of our study was the positive relation between current or previous tobacco use and clinical improvement with lithium treatment. Prevalence of tobacco use among patients with BD varies between $31.2 \%{ }^{37}$ to $66 \%{ }^{38}$. In our study the prevalence was of $31.58 \%$. This result conflicts with literature data in which the use of tobacco is more frequently associated with worst treatment outcomes and higher recurrence and severity rates in patients with $\mathrm{BD}^{37}$.

It is interesting to notice that both tobacco alkaloids and lithium reduce the activity of glycogen-synthase-kinase 3 (GSK3), through the increase of its phosphorylation, thus modulating cellular inflammatory and apoptotic pathways ${ }^{39,40}$. Nonetheless, we did not perform a detailed characterization of tobacco use in the assessed patients and for this reason we consider this finding as a secondary outcome which would demand a different study design to be properly investigated.

\section{Psychotic symptoms}

Our study found, in the multivariate model, an inverse relation between the number of mood episode with psychotic symptoms and clinical improvement with lithium treatment. This finding reinforces the hypothesis that lithium treatment tends to be less efficacious in these patients ${ }^{16-19}$. It is important to notice that our variable does not discriminate between mood incongruent and congruent psychosis, but 76\% of the assessed patients with psychotic features had, at some point of their clinical course, mood incongruent symptoms.

It is not clear if the presence of this symptoms indicate a particular form of BD or simply a non-specific manifestation that follows the subjacent mood symptoms ${ }^{41}$. It is a fact though, that psychotic features indicate a severe clinical presentation of the mood disorder, and is related with worst scores in the PANSS, YMRS and GAS scales ${ }^{18}$. Therefore, a possible explanation to this results concern the phenotype of the studied population, since what is labeled as bipolar disorder today is a significantly larger and more heterogeneous group than the manic-depressive disorder patients of the recent past ${ }^{42}$.

Our study has a number of limitations. First, as any other study in which patients are retrospectively assessed through the review of their medical charts, the obtained data is limited to the quality of these records, and the occurrence of missing data or poor descriptions of the patients' phenomenology during mood episodes are not rare. The sample size $(n=40)$ is also small, what can limit the predictive power of our conclusions. Hence, it is possible that the relation between psychosis and worse outcome with lithium treatment is incidental, and we could be dealing with a sample of patients affected with more severe forms of mental disorder.

Finally, we believe future studies exploring the relation between smoking habit and BD, with larger sample sizes and a more refined description of tobacco use, could lead to some interesting findings, possibly with implication in the clinical treatment of these patients.

\section{CONCLUSION}

We found that patients with higher number of mood episodes with psychotic symptoms had worse response to lithium maintenance treatment, what is in consonance with the available data in the literature.

\section{INDIVIDUAL CONTRIBUTIONS}

Study Design (LFALS, CEMB, CRD, ILC, RS); Data Collection (LFALS, JCL, SCRF, MLS); Charts Review (LFALS, JCL, SCRF); Scoring of the ALDA scale (LFALS, JCL); Database Formulation and Feeding (LFALS, JCL); Statistical Analysis (LFALS, CEMB, CRD); Analysis and Interpretation of the Data (LFALS, CEMB, CRD); Literature Review (LFALS); Article Redaction (LFALS, CEMB, CRD); Intellectual Content Review (CEMB, CRD, ILC); Article Review and Approval of the Final Version (LFALS, CEMB, CRD, ILC, JCL, RS, SCRF, MLS).

\section{CONFLICTS OF INTEREST}

The authors have no conflicts of interest to declare.

\section{REFERENCES}

1. Merikangas KR, Akiskal HS, Angst J, Greenberg PE, Hirschfeld RMA, Petukhova M, et al. Lifetime and 12-month prevalence of bipolar spectrum disorder in the National Comorbidity Survey replication. Arch Gen Psychiatry. 2007;64:543-52.

2. Fassassi S, Vandeleur C, Aubry J-M, Castelao E, Preisig M. Prevalence and correlates of DSM-5 bipolar and related disorders and hyperthymic personality in the community. J Affect Disord. 2014;167:198-205.

3. Kessler RC, Akiskal HS, Ames M, Birnbaum H, Greenberg P, Hirschfeld RMA, et al. Prevalence and effects of mood disorders on work performance in a nationally representative sample of U.S. workers. Am J Psychiatry. 2006;163:1561-8.

4. Clemente AS, Diniz BS, Nicolato R, Kapczinski FP, Soares JC, Firmo J0, et al. Bipolar disorder prevalence: a systematic review and meta-analysis of the literature. Rev Bras Psiquiatr. 2015; 37:155-61.

5. Leboyer M, Henry C, Paillere-Martinot M-L, Bellivier F. Age at onset in bipolar affective disorders: a review. Bipolar Disord. 2005;7:111-8.

6. Judd LL, Akiskal HS. The prevalence and disability of bipolar spectrum disorders in the US population: re-analysis of the ECA database taking into account subthreshold cases. J Affect Disord. 2003;73:123-31.

7. Pini S, de Queiroz V, Pagnin D, Pezawas L, Angst J, Cassano GB, et al. Prevalence and burden of bipolar disorders in European countries. Eur Neuropsychopharmacol. 2005;15:425-34.

8. ten Have M, Vollebergh W, Bij R, Nolen WA. Bipolar disorder in the general population in The Netherlands (prevalence, consequences and care utilisation): results from The Netherlands Mental Health Survey and Incidence Study (NEMESIS). J Affect Disord. 2002;68:20313. 
9. Simon GE. Social and economic burden of mood disorders. Biol Psychiatry. 2003;54: 208-15.

10. McElroy SL, Altshuler LL, Suppes T, Keck PE, Frye MA, Denicoff KD, et al. Axis I psychiatric comorbidity and its relationship to historical illness variables in 288 patients with bipolar disorder. Am J Psychiatry. 2001;158:420-6.

11. Cade JF. Lithium salts in the treatment of psychotic excitement. 1949. Bull World Health Organ. 2000;78:518-20.

12. Bowden CL, Brugger AM, Swann AC, Calabrese JR, Janicak PG, Petty F, et al. Efficacy of divalproex vs lithium and placebo in the treatment of mania. The Depakote Mania Study Group. JAMA. 1994;271:918-24.

13. Bowden CL, Calabrese JR, McElroy SL, Gyulai L, Wassef A, Petty F, et al. A randomized, placebo-controlled 12-month trial of divalproex and lithium in treatment of outpatients with bipolar I disorder. Divalproex Maintenance Study Group. Arch Gen Psychiatry. 2000;57:481-9.

14. Kleindienst N, Engel R, Greil W. Which clinical factors predict response to prophylactic lithium? A systematic review for bipolar disorders. Bipolar Disord. 2005;7:404-17.

15. Alda M, Grof P, Rouleau GA, Turecki G, Young LT. Investigating responders to lithium prophylaxis as a strategy for mapping susceptibility genes for bipolar disorder. Prog Neuropsychopharmacol Biol Psychiatry. 2005;29:1038-45.

16. Berghöfer A, Alda M, Adli M, Baethge C, Bauer M, Bschor T, et al. Long-term effectiveness of lithium in bipolar disorder: a multicenter investigation of patients with typical and atypical features. J Clin Psychiatry. 2008;69:1860-8.

17. Ananth J, Engelsmann F, Kiriakos R, Kolivakis T. Prediction of lithium response. Acta Psychiatr Scand. 1979;60:279-86.

18. Canuso CM, Bossie CA, Zhu Y, Youssef E, Dunner DL. Psychotic symptoms in patients with bipolar mania. J Affect Disord. 2008;111:164-9.

19. Fountoulakis KN, Kasper S, Andreassen O, Blier P, Okasha A, Severus E, et al. Efficacy of pharmacotherapy in bipolar disorder: a report by the WPA section on pharmacopsychiatry. Eur Arch Psychiatry Clin Neurosci. 2012; 262 Suppl:1-48.

20. Toni C, Perugi G, Mata B, Madaro D, Maremmani I, Akiskal HS. Is mood-incongruent manic psychosis a distinct subtype? Eur Arch Psychiatry Clin Neurosci. 2001;251:12-7.

21. Keller MB, Lavori PW, Andreasen NC, Grove WM, Shapiro RW, Scheftner W, et al. Test-retest reliability of assessing psychiatrically ill patients in a multi-center design. J Psychiatr Res. 1981;16:213-27.

22. Tonna M, De Panfilis C, Marchesi C. Mood-congruent and mood-incongruent psychotic symptoms in major depression: the role of severity and personality. J Affect Disord. 2012;141:464-8

23. Fennig S, Bromet EJ, Karant MT, Ram R, Jandorf L. Mood-congruent versus mood-incongruent psychotic symptoms in first-admission patients with affective disorder. J Affect Disord. 1996;37:23-9.

24. Yazici 0, Kora K, Üçok A, Tunali D, Turan N. Predictors of lithium prophylaxis in bipolar patients. J Affect Disord. 1999;55:133-42.

25. Rybakowski JK. Genetic influences on response to mood stabilizers in bipolar disorder: current status of knowledge. CNS Drugs. 2013;27:165-73
26. Grof P, Duffy A, Cavazzoni P, GrofE, Garnham J, MacDougall M, et al. Is response to prophylactic lithium a familial trait? J Clin Psychiatry. 2002;63:942-7.

27. Manchia M, Adli M, Akula N, Ardau R, Aubry J-M, Backlund L, et al. Assessment of Response to Lithium Maintenance Treatment in Bipolar Disorder: A Consortium on Lithium Genetics (ConLiGen) Report. PLoS One. 2013;8:e65636.

28. Grant BF, Stinson FS, Hasin DS, Dawson DA, Chou SP, Ruan WJ, et al. Prevalence, correlates, and comorbidity of bipolar I disorder and axis I and II disorders: Results from the National Epidemiologic Survey on Alcohol and Related Conditions. J Clin Psychiatry. 2005;66: 1205-15.

29. Karanti A, Bobeck C, Osterman M, Kardell M, Tidemalm D, Runeson B, et al. Gender differences in the treatment of patients with bipolar disorder: a study of 7354 patients. J Affect Disord. 2015;174:303-9.

30. Rubinow DR, Moore M. Sex-dependent modulation of treatment response. Dialogues Clin Neurosci. 2004;6:39-51.

31. Azorin JM, Bellivier F, Kaladjian A, Adida M, Belzeaux R, Fakra E, et al. Characteristics and profiles of bipolar I patients according to age-at-onset: findings from an admixture analysis. J Affect Disord. 2013;150:993-1000.

32. Magalhães PV, Dodd S, Nierenberg AA, Berk M. Cumulative morbidity and prognostic staging of illness in the Systematic Treatment Enhancement Program for Bipolar Disorder (STEP-BD). Aust N Z J Psychiatry. 2012;46:1058-67.

33. Müller-0erlinghausen B, Berghöfer A, Bauer M. Bipolar disorder. Lancet. 2002;359(9302):241-7.

34. Tondo L, Isacsson G, Baldessarini R. Suicidal behaviour in bipolar disorder: risk and prevention. CNS Drugs. 2003;17:491-511.

35. Jamison KR. Suicide and bipolar disorder. J Clin Psychiatry. 1997;58:47-51.

36. Angst J, Angst F, Gerber-Werder R, Gamma A. Suicide in 406 mood-disorder patients with and without long-term medication: a 40 to 44 years' follow-up. Arch Suicide Res. 2005;9:279-300

37. Waxmonsky JA, Thomas MR, Miklowitz DJ, Allen MH, Wisniewski SR, Zhang H, et al. Prevalence and correlates of tobacco use in bipolar disorder: data from the first 2000 participants in the Systematic Treatment Enhancement Program. Gen Hosp Psychiatry. 2005;27:321-8.

38. Diaz FJ, James D, Botts S, Maw L, Susce MT, De Leon J. Tobacco smoking behaviors in bipolar disorder: a comparison of the general population, schizophrenia, and major depression. Bipolar Disord. 2009;11:154-65.

39. Jope RS. Glycogen synthase kinase-3 in the etiology and treatment of mood disorders. Front Mol Neurosci. 2011;4:16.

40. Tian D, Zhu M, Li J, Ma Y, Wu R. Cigarette smoke extract induces activation of beta-catenin/ TCF signaling through inhibiting GSK3beta in human alveolar epithelial cell line. Toxicol Lett. 2009;187:58-62

41. Swann AC, Daniel DG, Kochan LD, Wozniak PJ, Calabrese JR. Psychosis in mania: specificity of its role in severity and treatment response. J Clin Psychiatry. 2004;65:825-9.

42. Akiskal HS, Bourgeois ML, Angst J, Post R, Möller H-J, Hirschfeld R. Re-evaluating the prevalence of and diagnostic composition within the broad clinical spectrum of bipolar disorders. J Affect Disord. 2000;59:55-30. 
APPENDIX 01 - BRAZILIAN VERSION OF THE ALDA SCALE

Critérios Retrospectivos da Resposta Terapêutica de Longo Prazo em Pacientes com Transtorno Afetivo Bipolar

Nome:

Data:

Droga:

Avaliador:

\begin{abstract}
Critério A severidade e duração dos episódios.

$10=$ Resposta completa. Sem recorrência na vigência de tratamento adequado, sem sintomas residuais, recuperação funcional completa residuais mínimos (ansiedade transitória, alterações no padrão do sono, disforia, irritabilidade) sem que seja necessária qualquer intervenção

$\mathbf{8}=$ 0́tima resposta. Atividade da doença reduzida mais que $90 \%$

$7=$ Boa resposta. Atividade da doença reduzida em $80-90 \%$

$6=$ Boa resposta. Atividade da doença reduzida em $65-80 \%$

$\mathbf{5}=$ Resposta moderada. Atividade da doença reduzida em 50-65\%

$4=$ Resposta moderada. Atividade da doença reduzida em 35-50\%

3 = Melhora leve. Atividade da doença reduzida em 20-35\%

$\mathbf{2}=$ Melhora leve. Atividade da doença reduzida em 10-20\%

1 = Melhora mínima. Atividade da doença reduzida em 0-10\%

$\mathbf{0}=$ Sem mudança ou piora
\end{abstract}

0 critério A é usado para determinar associação entre melhora clínica e tratamento. A análise deve se referir ao período de tratamento considerado adequado em termos de duração e dosagem das medicações. A atividade da doença deve ser avaliada quanto a frequência,

$\mathbf{9}=$ Ótima resposta. Sem recorrência de episódios, porém o paciente pode ter sintomas

\section{Critérios B}

Os critérios B são usados para estabelecer se existe uma relação causal entre melhora clínica e 0 tratamento instituído. Atribua 0,1 ou 2 pontos para cada item.

\section{B1: Número de episódios antes do tratamento:}

$0=4$ ou mais episódios

$1=2$ ou 3 episódios

$2=1$ episódio

B1:

B2: Frequência dos episódios antes do tratamento:

$0=$ Moderada a alta, incluindo ciclagem rápida

1 = Baixa, com remissões espontâneas, de três anos ou mais em média

2 = 1 único episódio, risco de recorrência não pode ser estabelecido

B2:

\section{B3: Duração do tratamento:}

$0=2$ ou mais anos

$1=1$ a 2 anos

$2=$ Menos que 1 ano

B3:

B4: Adesão durante período de estabilidade:

$0=$ Excelente; documentado por dosagens séricas em nível terapêutico

$1=$ Boa; mais que $80 \%$ das dosagens séricas em nível terapêutico

2 = Pobre; repetidamente abandona tratamento, menos que $80 \%$ das dosagens séricas em nível terapêutico

B4:

B5: Uso de medicação adicional durante período de estabilidade.

$0=$ Nenhuma, exceto medicação para dormir eventual (uso semanal ou menor frequência); sem outros estabilizadores do humor, antidepressivos ou antipsicóticos para controle dos sintomas

1 = Antidepressivos em baixa dose ou antipsicóticos "por segurança" ou uso prolongado de medicação para dormir

2 = Uso prolongado ou sistemático de antidepressivos ou antipsicóticos

B5:

Total de pontos Critérios B: Total de pontos da escala (subtrair B de A): 